\title{
Assessment of Shopping Malls Accessibility: Case Study of Krakow
}

\author{
Anton Pashkevich \\ Associate Professor, Cracow University of Technology, Poland \\ Sabina Pulawska \\ Assistant Professor, Cracow University of Technology, Poland
}

\section{SUMMARY}

The main aim of presented study was to analyze and to assess accessibility of shopping malls as traffic generators in the city of Krakow (Poland) as well as to compare calculated results in the perspective of the whole amount of shopping centers. The scope of research work includes the calculation of two kinds of accessibility measures: distance measures based on the straight line (Euclidean distance) and real distances and potential accessibility measures also based on the same distances and, additionally, weighted by characteristics of shopping malls and transport districts. The data from the OpenStreetMap project was used to get information concerning transport network and two kinds of above-mentioned distances. At the end of article a possible usage of obtained results and the further development of topic are described.

\section{INTRODUCTION}

Concept of accessibility is used in many fields of science - in spatial planning, transport planning, geography or in the social sciences. However, the definition of accessibility isn't clearly understood. The most-known definition, among spatial and transport planners, is Hansen's (1959) definition, that indicate the accessibility as "the potential of opportunities for interaction". After Hansen's publication, over the decades, many other researcher tried to describe accessibility in the own way, for example: Nakkash (1969) introduced "the operational definition of the accessibility of a zone to each activity was defined as the sum of the products of the size of each activity in each zone of the study area and the friction factor corresponding to the travel time between each zone and the zone under consideration", Dalvi and Martin (1976) understood accessibility as "the ease with which any land-use activity can be reached from a location using a particular transport system", Burns (1979) defined accessibility as "the freedom of individuals to decide whether or not to participate in different activities", authors Ben-Akiva and Lerman (1979) indicated that accessibility determinates "the benefits provided by a transportation/land-use system", Johnston et al. (1994) presented the simplest definition: "the ease with which one place can be reached from another". According to this approach, one of the latest research and accessibility analysis are provided by Geurs and Van Wee (Geurs, van Wee, 2013), who defined accessibility "as the extent to which land-use and transport systems enable (groups of) individuals to reach activities or destinations by means of a (combination of) transport mode(s)." 
During two last decades, a great number of shopping malls ${ }^{1}$ was built. It was taken place together with evaluation of their commercial functions: they started to be not only places for shopping, but also to include a large amount of different attractions for people. This fact increased a significance of shopping malls for transport planning as generators of traffic. Basic parameters used to describe their attractiveness are gross leasable area (GLA), a number of shops and outlets as well as an amount of parking places.

Accessibility analysis can provide the important tool to support decision making process in planning, taking into account transport network planning as well as sustainable, public transport and user oriented spatial planning. The conducted accessibility analysis may be a relative assessment of the quality of residents' life. Measures may indicate places with insufficient transport services, requiring additional investment in infrastructure.

\section{RESEARCH OBJECTS AND AREA}

This chapter presents general information concerning research objects and research area, which are shopping malls and the city of Krakow, respectively.

\subsection{Definition and classification of shopping malls}

Development and growth of shopping area push designers and engineers to clarity definition and classification of shopping centers.

In Poland the term of large-area shopping objects is used. This term came from the special legal act and means an object, in which commercial activities is carried out and which sales area is more than 400 square meters $\left(\mathrm{m}^{2}\right)$.

The International Council of Shopping Centers (ICSC) defines shopping center as "a group of retail and other commercial establishments that is planned, developed, owned and managed as a single property, typically with on-site parking provided"2. Term of so-called European shopping center adds a common definition which following restrictions:

- minimum GLA must be $5000 \mathrm{~m}^{2}$;

- shopping center must include retail and service units as well as "communal" areas.

The most common classification of shopping centers was formed in connection with their evolution in time and takes into account the next generations of shopping malls. Name of their types is related only to the expansion of offered functions. It does not mean that building of the previous generation shopping centers is stopped after the appearance of new generation.

The first generation includes objects, which main part of area is occupied by hypermarket. In such situation, hypermarket covers more than $4000 \mathrm{~m}^{2}$, which is normally around $70 \%$ of the whole shopping mall area. The rest of space is used by shops and service points, which complement offers of hypermarket. In additional, such shopping centers have a large open-

1 Terms "shopping mall" and "shopping center" are used as synonyms in this article.

$2 \mathrm{http} / / / \mathrm{www}$.icsc.org/research/references/c-shopping-center-definitions 
space parking, because the most of them are situated on the city periphery where built-up density is not so high. TESCO on the street Wielicka and Carrefour on the street Witosa are examples of such shopping malls in Krakow.

In the case of shopping malls relating to the second generation, area used by the main tenant is reduced to $30-40 \%$. It does not mean certainly that space occupied by hypermarket is decreased, but it connects often with growth of the total shopping center area. The rest part is used by small shops and service points, which spread often over a number of floors. Due to location closer to the city centers, these objects occupy a smaller area in comparison to shopping malls of previous generation and have more complicated form. In Krakow there are 5 such shopping malls: M1 Kraków, CH Czyżyny, CH Krokus, TESCO on the street Kapelanka and Solvay Park.

The next generation of shopping centers are located mostly in the city center and created by individual architectural concepts. Parking places are situated normally over the shopping space or under the ground, which requires to build multi-floor construction. Shopping malls of the third generation allow to guarantee a richer offer for users. To realize such offer, these objects is enriched mainly by gastronomy and entertainment services including, for example, cinema, gym, bowling, etc. Galeria Krakowska, Galeria Kazimierz and Kraków Plaza in Krakow are shopping malls, which could be entered in the list of the third generation.

Shopping malls of the fourth generation are even more diverse and multifunctional in relation to the previous one. They start to have hotel services and offices. Their extensive offer includes museums, art galleries, clubs, SPA and other innovative ideas. Originality and adaptation of large territory are the main features of architectural concepts by building of these centers. In Krakow there are 2 shopping malls of the fourth generation: Bonarka City Center and Galeria Bronowice.

Researchers and experts define also the fifth generation of shopping malls. They will look like small complex towns, which will have a part for living areas. Residents will carry out all their needs within such shopping mall, which could include entertainment, health care, children-care facilities and even work places in offices.

\subsection{Characteristics of shopping malls in the city of Krakow}

As it was mentioned above, the main research objects of this paper are shopping malls. At the moment, there are 12 places in Krakow, which satisfy the requirements to be shopping centers. All of them will be considered by calculation and analysis. The main characteristics affecting their attractiveness are following:

- gross leasable area (GLA);

- the number of parking places;

- the number of shops.

Table 1 presents information concerning generations of all shopping malls and their main relevant features. Locations of the research objects in the territory of Krakow are shown on the Figure 1 as orange points. 


\begin{tabular}{|c|l|c|c|c|c|}
\hline Number & Object & Generation & $\begin{array}{c}\text { Shopping area } \\
\text { GLA (m2) }\end{array}$ & Parking places & $\begin{array}{c}\text { Number } \\
\text { of shops }\end{array}$ \\
\hline $\mathbf{1}$ & $\begin{array}{l}\text { Bonarka City } \\
\text { Center }\end{array}$ & IV & 92940 & 3200 & 270 \\
\hline $\mathbf{2}$ & $\begin{array}{l}\text { Galeria } \\
\text { Bronowice }\end{array}$ & IV & 60000 & 2400 & 150 \\
\hline $\mathbf{3}$ & $\begin{array}{l}\text { Galeria } \\
\text { Krakowska }\end{array}$ & III & 60000 & 1400 & 270 \\
\hline $\mathbf{4}$ & $\begin{array}{l}\text { Galeria } \\
\text { Kazimierz }\end{array}$ & III & 40000 & 1300 & 155 \\
\hline $\mathbf{5}$ & Kraków Plaza & III & 31000 & 1500 & 155 \\
\hline $\mathbf{6}$ & M1 Kraków & II & 50000 & 1350 & 117 \\
\hline $\mathbf{7}$ & CH Czyżyny & II & 31015 & 865 & 73 \\
\hline $\mathbf{8}$ & CH Krokus & II & 30190 & 1100 & 58 \\
\hline $\mathbf{9}$ & $\begin{array}{l}\text { TESCO } \\
\text { (Kapelanka Str.) }\end{array}$ & II & 25500 & 600 & 42 \\
\hline $\mathbf{1 0}$ & Solvay Park & II & 13800 & 207 & 55 \\
\hline $\mathbf{1 1}$ & $\begin{array}{l}\text { TESCO } \\
\text { (Wielicka Str.) }\end{array}$ & I & 25400 & 308 & 29 \\
\hline $\mathbf{1 2}$ & $\begin{array}{l}\text { Carrefour } \\
\text { (Witosa Str.) }\end{array}$ & I & 9000 & 350 & 11 \\
\hline $\mathbf{1 0}$ & Characteristics & shoping & & \\
\hline
\end{tabular}

Table 1 - Characteristics of shopping malls in the city of Krakow

\subsection{Research area - the city of Krakow}

All shopping malls are located in the city of Krakow. The city is situated in the Małopolska Province and is its capital. Its total area is around $327 \mathrm{~km}^{2} \mathrm{~km} 2$. According to the Polish Central Statistical Office, population of Krakow in the year 2015 was 762508 inhabitants. Due to its historical impotrance and cultural events, this city is one of the most popular tourist center in the whole country.

The city consists administratively of 18 areas. Taking into account research needs in the field of transport, homogeneous travel behaviors and traffic barriers such as river Vistula or streets of high classes, Krakow was divided into 362 transport districts, which are called sometimes communication areas. Each of districts has its gravity center, which is defined with the help of geographical coordinates. A gravity center is a point, where all trips done by inhabitants of these transport district start and end. Besides of that, each transport district has a number of features including population size, number of working people, number of working places, amount of living area, etc. Within the scope of article research, only one characteristic will be taken into account - a number of district inhabitants.

On the Figure 2 the map of Krakow is presented. Red lines are boundaries of transport districts, which gravity centers are shown as green points. As it was mentioned above, shopping malls were pointed out as orange nodes. 


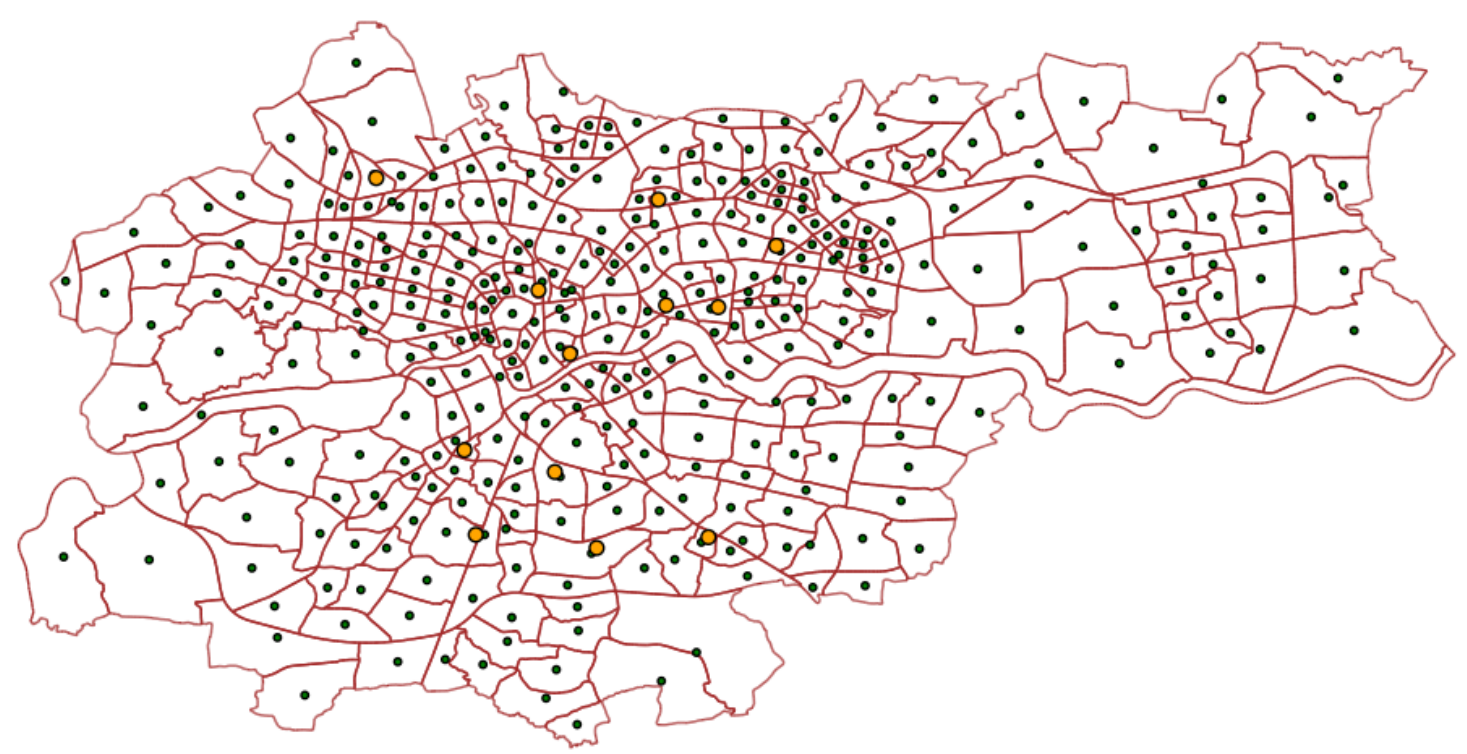

Fig. 1 - Map of Krakow with shopping malls, transport districts and their gravity centres

Another important data concerning research area is an information about the road network. It is needed to make an assessment of real distances between chosen places. These distances will be used for calculation, which will be presented below.

One of GIS data sources is digital maps. OpenStreetMap was chosen as a storage to get necessary information about road network. Only roads of high categories were taken into account to calculate the main part of real distances. Roads of low categories were kept in mind only to identify access ways. Roads of high categories are marked with green color on the Figure 2 (boundaries of the city and transport districts are red).

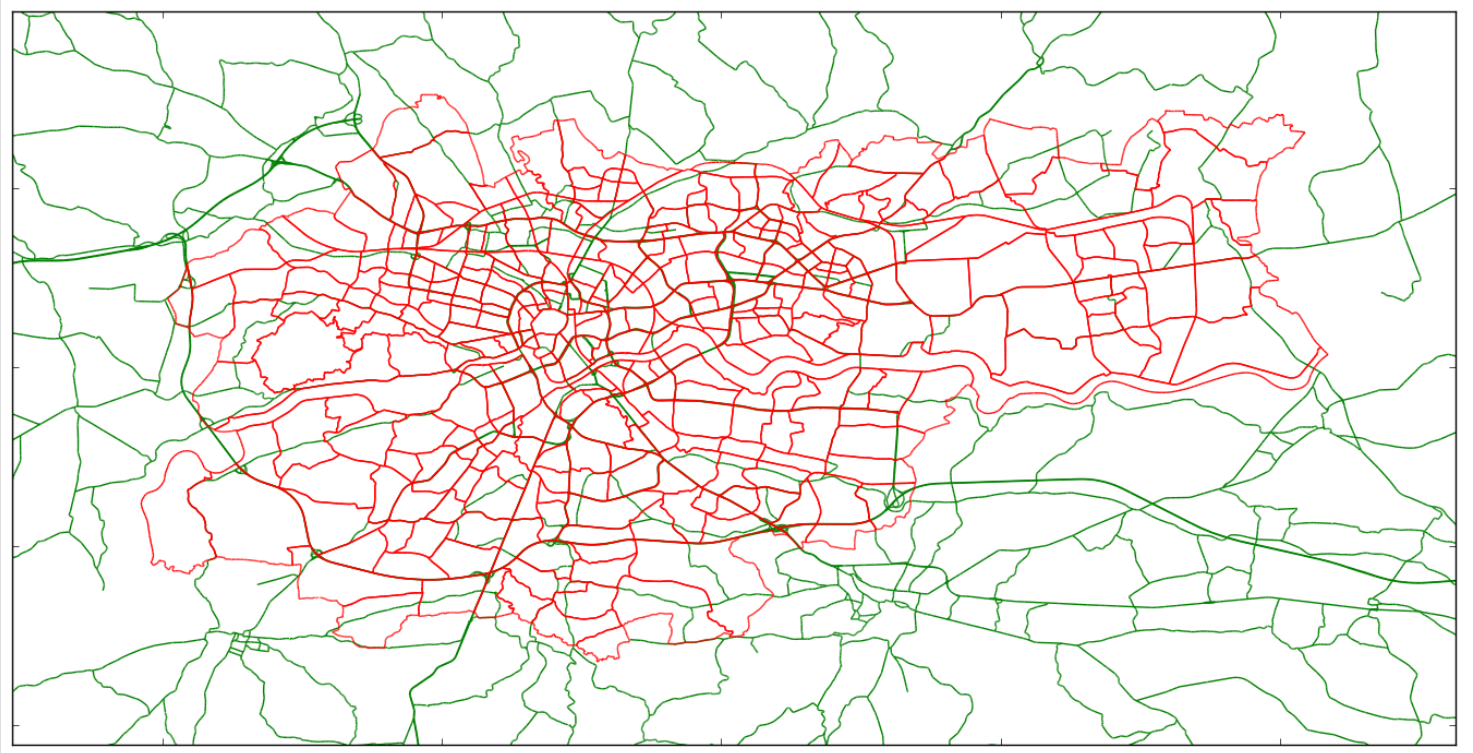

Fig. 2 - Road network on the territory of Krakow and its surrounding

\section{ACCESSIBILITY MEASURES}

This work is licensed under a Creative Commons Attribution-NonCommercial-NoDerivatives 4.0 International License (CC BY-NCND 4.0). 
Simultaneously to the development of accessibility concept, accessibility modeling methods were created, which are based on different assumptions. All these approaches could be divided into following groups:

- Infrastructure-based measures;

- Location-based measures including distance measures, contour measures and potential/gravity-based accessibility measures;

- Competition measures;

- Utility-based measures.

Depending on the analysis goals, different methods can be used. Most models are using GIS databases. Above-mentioned measures are differ from each other with usability, flexibility, necessity of having hardly available data.

To conduct the accessibility analysis presented in this paper, the location-based measures were used. The calculations were based on Euclidean and real distance, demographic data (population size of each transport district) and the data about shopping malls' features that affect their attractiveness:

- GLA (gross leasable area) surface;

- the number of parking places;

- the number of shops.

The Figure 3 shows the place of the chosen accessibility measures in the general classification as well as presents their details.

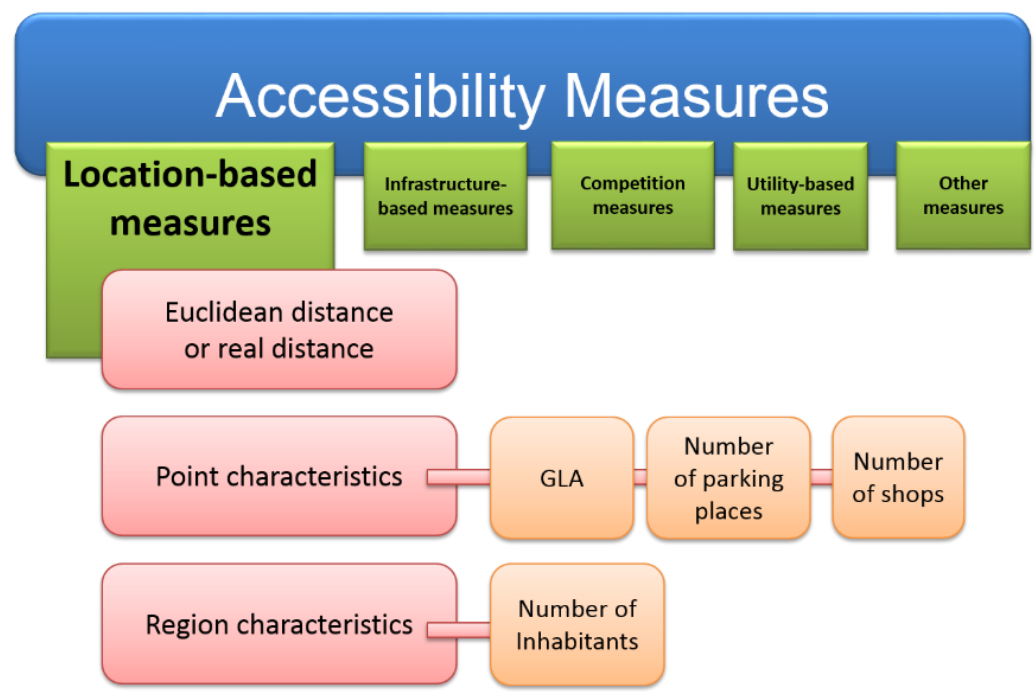

Fig. 3 - Accessibility measures used in the research study

The main aim of the research study is to calculate measures which give possibility to assess accessibility of each shopping mall in relation to the whole city area. In such situation, each shopping center is a destination and each transport district is an origin of a potential trip. To make such calculation and its future analysis, two group of simple location-based measures 
were used: distance measures and potential measures. In general, the research study considered 5 measures: one from the first group and five from the second one.

The measure from the first group will be called "distance measure". It is an average distance from all transport districts to chosen shopping mall. It means that this measure must be calculate for each shopping center separately with help of the following formula:

$$
M_{1 i}=\frac{\sum_{j=1}^{n} d_{i j}}{n}, \quad i=1 \ldots m, \quad j=1 \ldots n
$$

where:

- $\quad d_{i j}$ - distance from shopping mall $i$ to transport district $j$

- $n$ - a number of transport districts

- $\quad m$ - a number of shopping malls

Potential measures are divided into measures weighted by the features of shopping center and measure, which is calculated taking into account a population size of each transport district. The general formula of the first ones is following:

$$
M_{K i}=\frac{\sum_{j=1}^{n} d_{i j}}{1000 \cdot n \cdot \frac{f_{i}}{\sum_{i=1}^{m} f_{i}}}, \quad i=1 \ldots m, \quad j=1 \ldots n
$$

where:

- $\quad d_{i j}$ - distance from shopping mall $i$ to transport district $j$

- $n$ - a number of transport districts

- $m$ - a number of shopping malls

- $f_{i}$ - value of selected feature concerning shopping mall $i$

$f_{i}$ could describe one of 3 above-mentioned characteristics: GLA surface (measure $M_{2 i}$ ), the number of parking places (measure $M_{3 i}$ ) or the number of shops (measure $M_{2 i}$ ). These measures assess accessibility taking into account attractiveness of the shopping malls. With other words, attractiveness is evaluated with help of characteristics, which potential client (inhabitant of the city) could consider by making a choice of shopping center.

Potential measure weighted by the number of city inhabitants is calculated in the following way: 


$$
M_{5 i}=\frac{\sum_{j=1}^{n} d_{i j} \cdot h_{j}}{\sum_{j=1}^{n} h_{j}}, \quad i=1 \ldots m, j=1 \ldots n
$$

where:

- $\quad d_{i j}$ - distance from shopping mall $i$ to transport district $j$

- $n$ - a number of transport districts

- $m$ - a number of shopping malls

- $h_{j}$ - population of transport district $j$

Measure $M_{5 i}$ presents an average trip length for one city inhabitant.

The calculation of each measure was done in two versions:

- The version 1 is based on Euclidean distance measured in a straight line from origin to destination;

- The version 2 takes into account real distances between origins and destinations on the road network.

Such division is used in the whole paper, especially, by description of diagrams in the chapter 5 .

As it was mentioned above, the source OpenStreetMap was a basic to find real distances. A specially developed software based on Python programming language was used for getting and processing of necessary GIS data. Within the scope of this research study, real distance is considered as the shortest route from origin to destination using the existing road network. The part of the road network which was involved to assess real distances is presented on the Figure 4 with the help of deep red color.

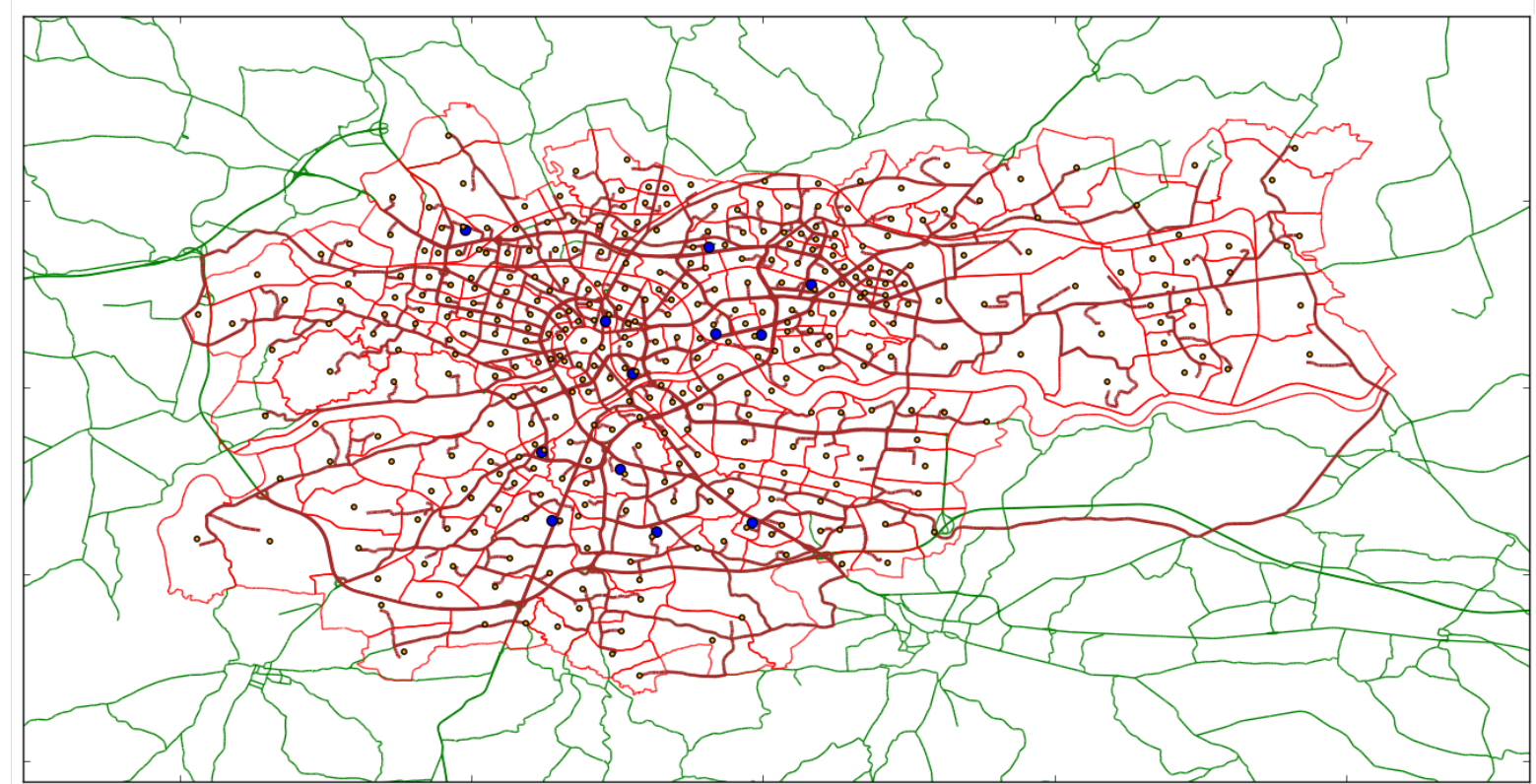

Fig. 4 - Road network used to reach shopping malls from transport districts 


\section{RESULTS OF CALCULATIONS}

The first result of research study is a calculation of all above-described measures. In general, there are 5 measures in 2 version (together 10) for each shopping center.

Values of measure $M_{1}$ for all shopping malls are shown on the Figure 5.

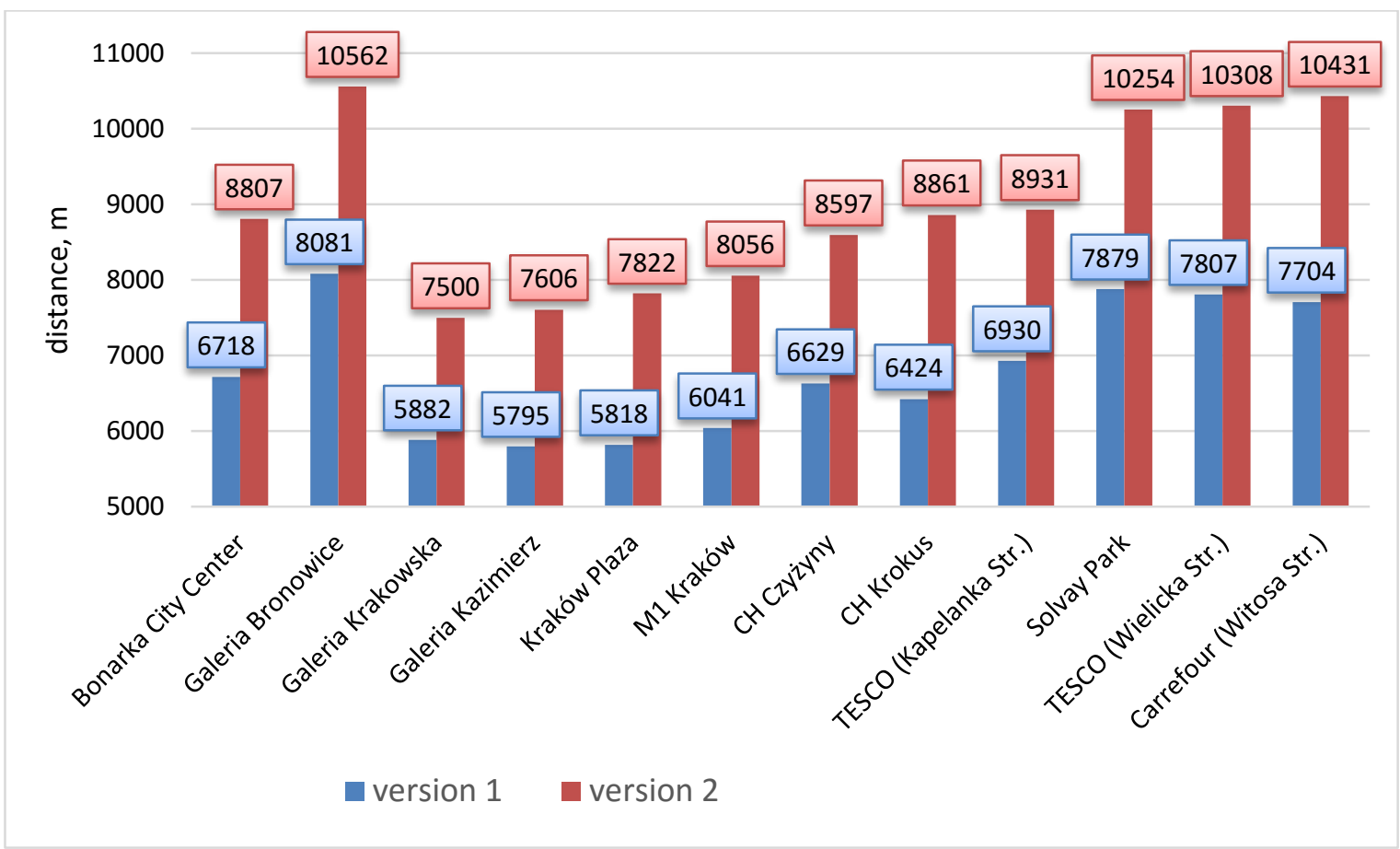

\section{Fig. 5 - Measure M1 for all shopping malls}

As it is seen from the Figure 5, Galerii Kazimierz has the shortest average distance according to the version 1, which is $5795 \mathrm{~m}$. The shopping center Krakow Plaza stays quite near -5818 $\mathrm{m}$. The third place is taken by Galeria Krakowska with value $5882 \mathrm{~m}$. According to measure $M_{1}$ based on the real distances, the best accessibility have the same shopping malls: Galeria Krakowska (7500 m), Galeria Kazimierz (7606 m) and Krakow Plaza (7822 m). All these objects are situated near the city center and belong to the third generation. In reality, in spite of good location only shopping mall Krakow Plaza does not have such great popularity between population as another 2 centers.

For both versions of measure $M_{1}$ the largest average distance to all transport districts has Galerie Bronowice, which is located in the northern part of the city. On the one hand, its accessibility has clearly the worst value in the case of Euclidean distances, on the other hand, if real distances are taken into account, accessibilities of Solvay Park, TESCO (Wielicka Str.) and Carrefour (Witosa Str.) are close to the worst one.

$M_{2}$ is based on distances between shopping malls and transport districts as the first measure, and also it is weighted by GLA surface of each shopping center. The Figure 5 illustrates its values. 
Bonarka City Center got the best value for both distance versions. The main role here plays its large shopping area, which had much greater influence on the calculation results in comparison with geographical location: previous measure $M_{1}$ put it on the 7 th and 6th places in the general ranking depending on calculation version.

The large value of GLA and position in the city center guarantee the second place for Galeria Krakowska. The third ranking position took M1 Krakow, which has quite big shopping area despite the fact that it belongs to shopping malls of the second generation.

The worst accessibility has Carrefour (Witosa Str.). The reason is the smallest value of chosen characteristic as well as location in the suburban area.

The calculated measures $M_{2}$ show similar accessibility rankings of shopping centers in terms of chosen types of distances. Only one difference presented on the Figure 5 is places of CH Krokus and CH Czyżyny, which values for both calculation versions are close to each other.

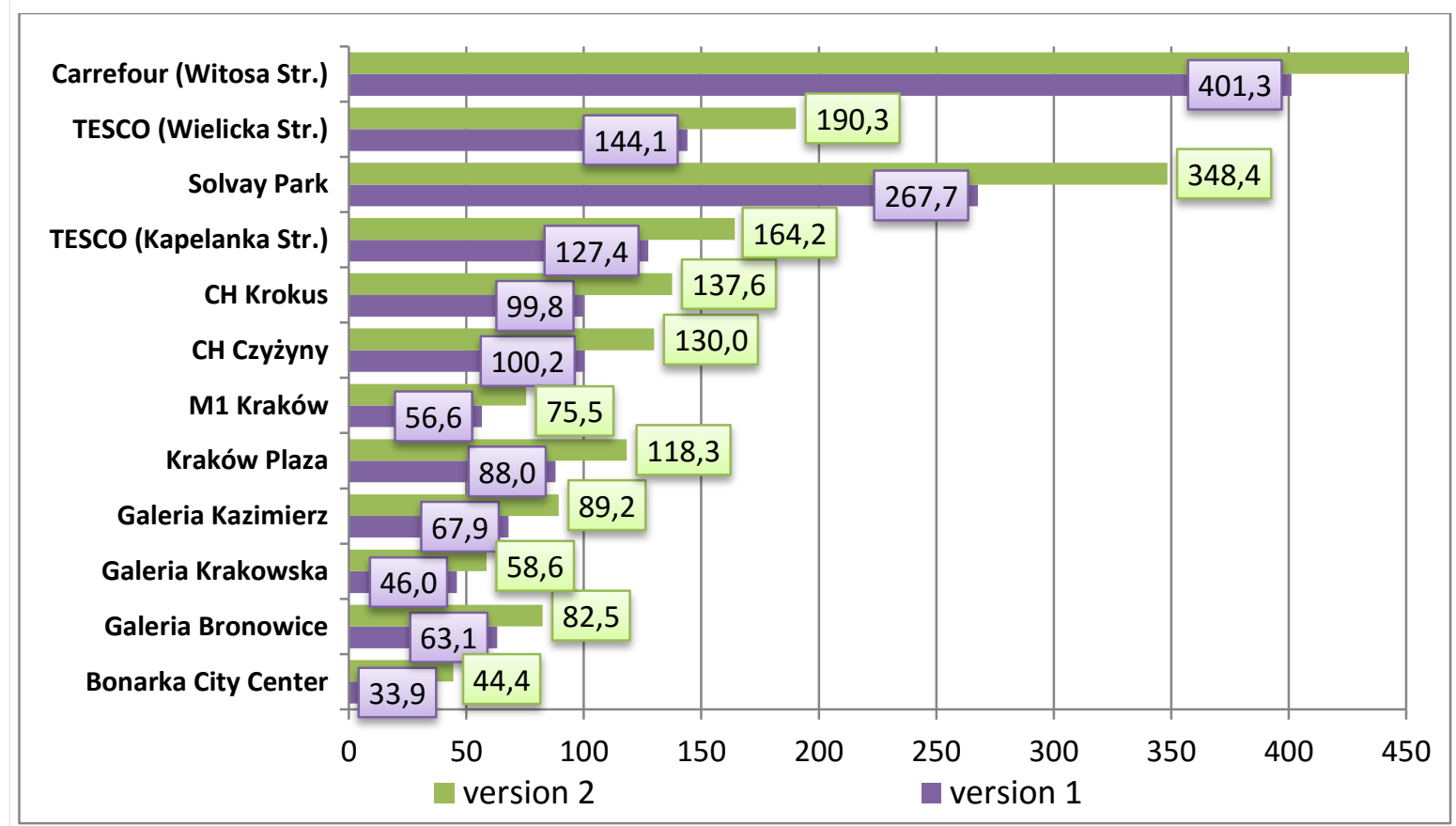

Fig. 5 - Measure M2 for all shopping malls

Each shopping center has its own parking, which size is restricted by regulation of the city transport policy depending on the location of particular mall. The large number of parking places motivate customers additionally to visit shops by car. The next measure is weighted by the size of shopping center parking.

As it is shown on the Figure 6, the best accessibility according to measure $M_{3}$ has Bonarka City Center. It has the largest parking through shopping objects in Krakow - 3200 parking places. Also this shopping mall is situated relatively near to the city center.

The second and third positions in the ranking order are occupied by Galeria Bronowice and Krakow Plaza, respectively. It corresponds directly to ranking of parking size, where they take the same places. 
The largest value of the measure $M_{3}$ got Solvay Park, which has the smallest parking between all cosidered shopping malls and is situated in suburban area.

The results for both calculation versions present the same accessibility ranking of shopping center. Based on analysis of features influenced on such order system, it is fair to say that accessibility ranking of shopping centers is closely depended on an amount of parking places. Only in the case of shopping centers Galeria Kazimierz and Krakow M1 calculted result shows better accessibility for the object with the smaller number of parking places. From the other side, the difference is quite a little (50 parking places).

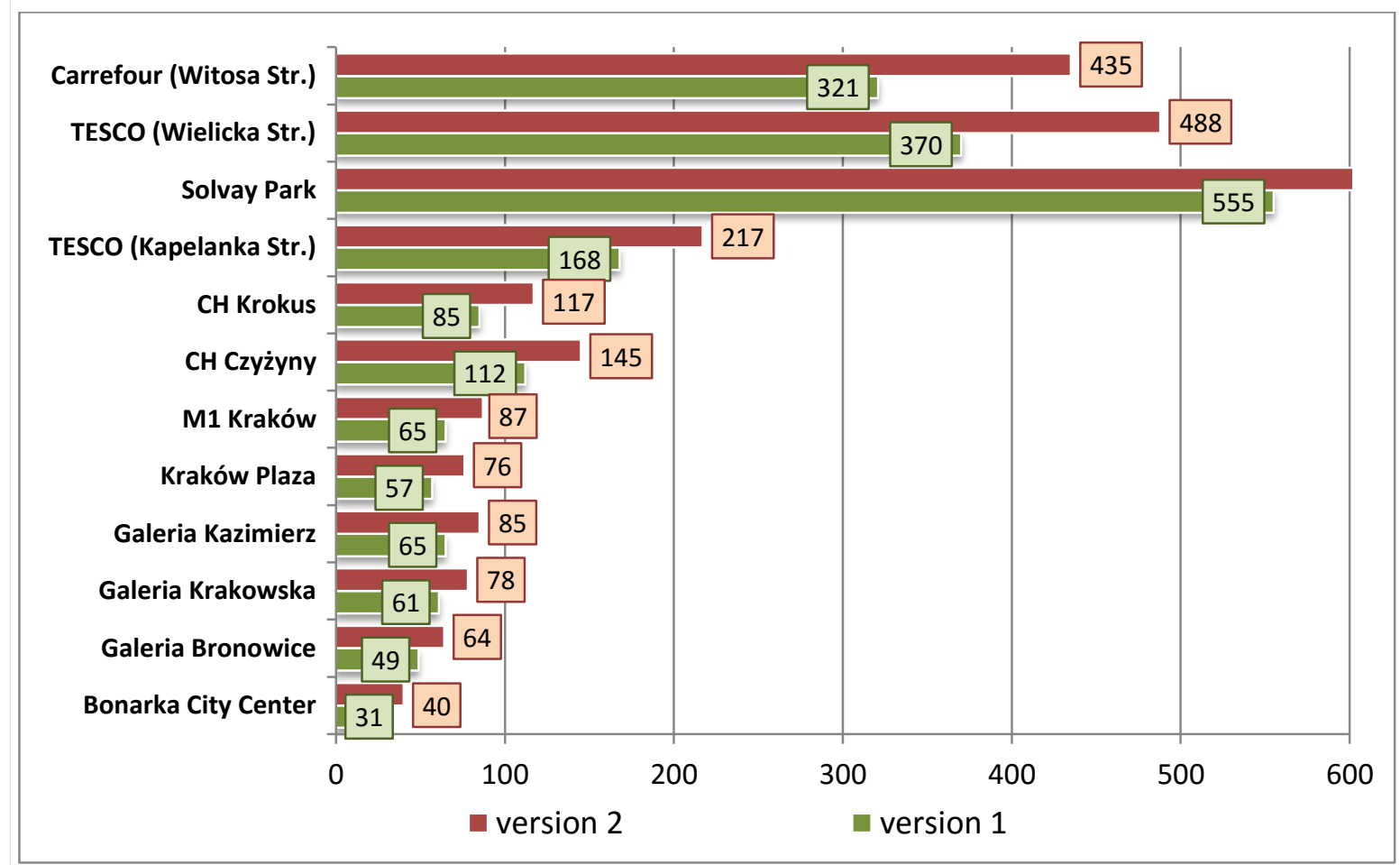

Fig. 6 - Measure M3 for all shopping malls

The next feature is a number of shops. Measure $M_{4}$ is weighted by this characteristic. The results of calculation are on the Figure 7.

The best value for measure $M_{4}$ independently of distance type was shown by Galeria Krakowska. This object has the same number of shops as the largest mall Bonarka City Center, but is situated in the city center: an average distance from this shopping center to transport districts is lower. Logically, Bonarka City Center takes the second place in the ranking. The third position is for Galeria Kazimierz and Krakow Plaza, which values of measure $M_{4}$ are quite similar.

Cerrefour (Witosa Str.) has the worst accessibility according to cosidered measure. The reasons are small amount of shops (only 11) and location in suburban areas of the city. 


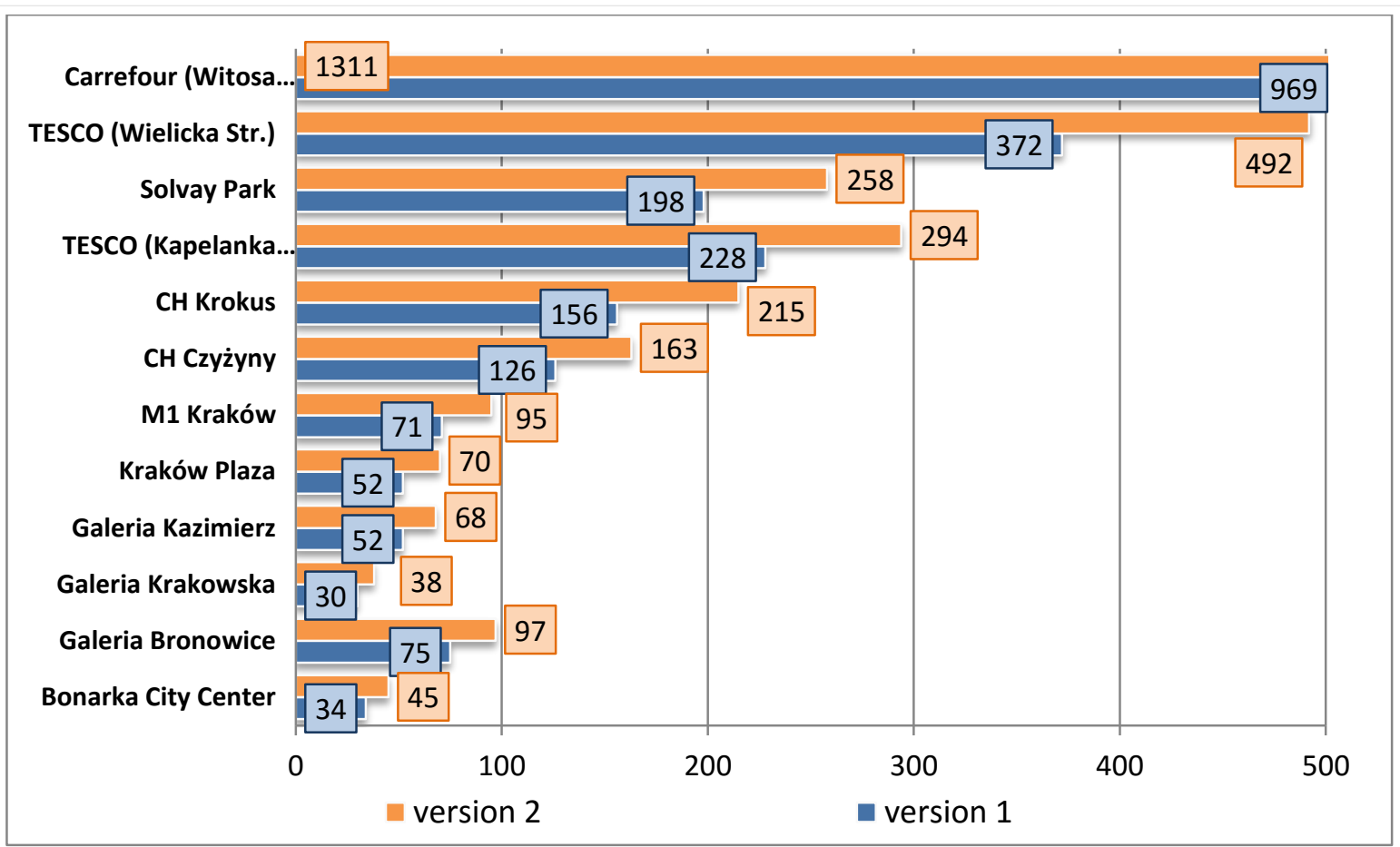

Fig. 7 - Measure M4 for all shopping malls

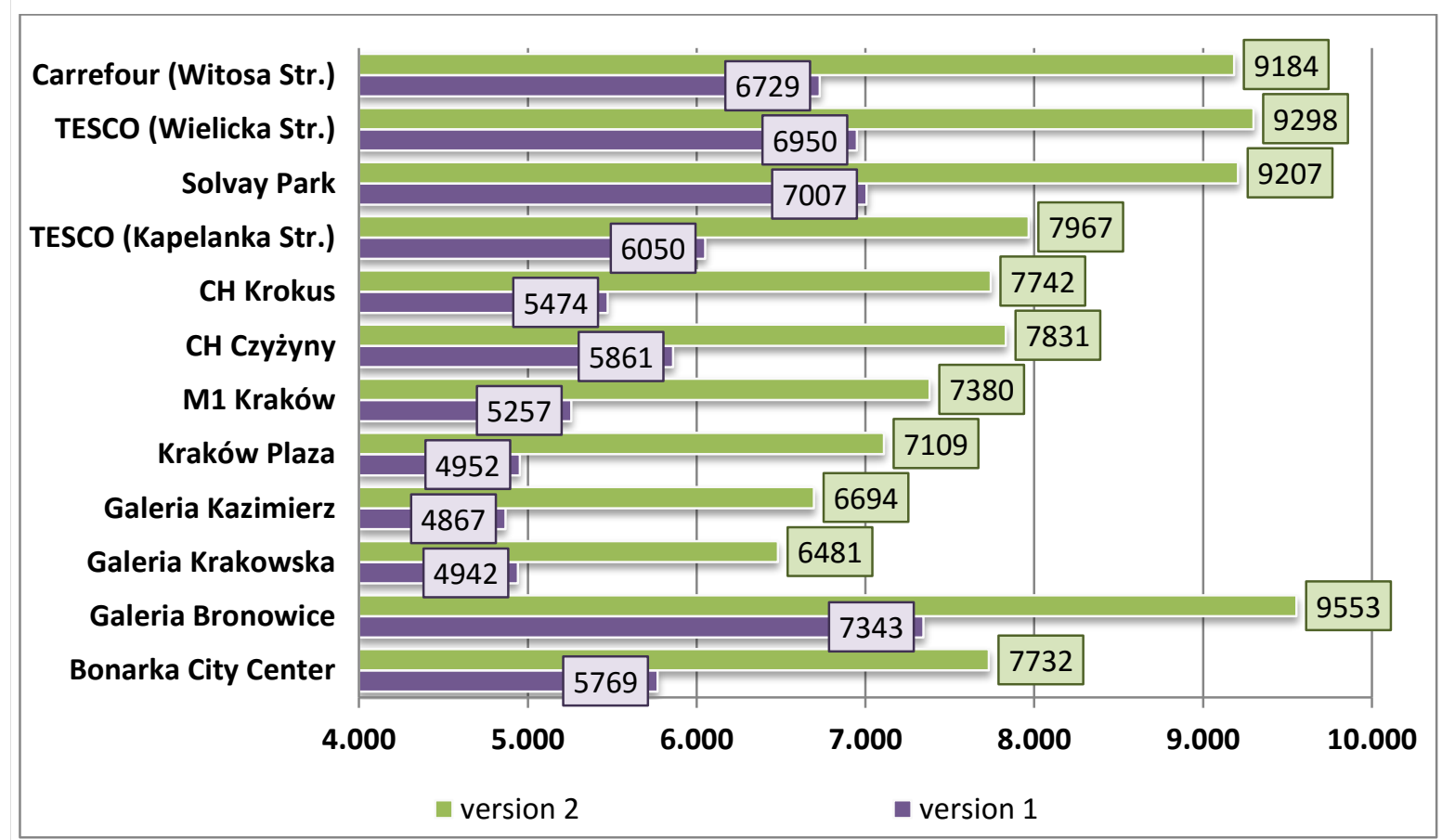

Fig. 8 - Measure M5 for all shopping malls

The next measure $M_{5}$ takes into account population sizes of all transport districts. The Figure 8 presents results of accessibility calculation based on this measure.

It is very important to include inhabitants of the city, because they are the main clients of the considered objects. These measures do not indicate clearly the best accessible shopping mall. On the one hand, according to the first version, Galeria Kazimierz it is the most accessible object. On the other hand, according to the real distances, the best value of measure has 
Galeria Karkowska. Such results are explained by the following fact: transport districts with the high population density are situated near the city center, which guarantees shorter length of trips for more city residents. The worst accessibility for both calculation versions is shown by Galeria Bronowice, which is result of its location in the suburban area as well as locations of transport districts with low population density around this shopping mall.

\section{CONCLUSIONS AND DISCUSSIONS}

In the chapter 5 all defined measures were calculated in two versions for each shopping mall. Calculation versions were based on two different types of distances: Euclidean and real. For potential measures 3 features of shopping centers and one feature of transport districts were chosen: GLA surface, a number of parking places, a number of shops and population sizes. Below there is a summary of three measures, which take into account the characteristics of shopping centers and are calculated in two variants. These diagrams allow to find shopping mall in Krakow with the best accessibility in relation to another malls. On the Figure 9 there is a comparison of results for potential measures based on Euclidean distance. As it is seen from this Figure, Bonarka City Center has the best level of accessibility. Despite the fact that the best result for $M_{3}$ is for Galeria Krakowska, shopping center with largest GLA surface in Krakow has the most preferable values for other two measures. The extremely negative results can be seen for Carrefour (Witosa Str.) and Solvay Park considering measures $M_{4}$ and $M_{3}$ respectively.

Measures based on real distances are presented on the Figure 10. Conspicuously, diagram has a similar form in comparison with previous one. Taking into account real distances based on the road network, values of measures for the second version are much higher: for example, potential measures weighted by a number of shops for Carrefour (Witosa Str.) differ by the value of 343 between each other.

According to the described Figures, it is fair to say that measures based on Euclidean distances and measures based on real distances return the same level of accessibility for each shopping center in comparison with the rest of objects. In the same time it must be pointed out that it is impossible to emphasize clearly one object with the worst level of accessibility. In such case a group of shopping malls should be marked: Solvay Park, TESCO (Wielicka Str.) and Carrefour (Witosa Str.). This centers have the biggest values of all calculated measures in relation to other ones. The reason for the selection of this groups is multi-criterial approach, in which potential customer bases a destination choice taking into account a combination of factors. 


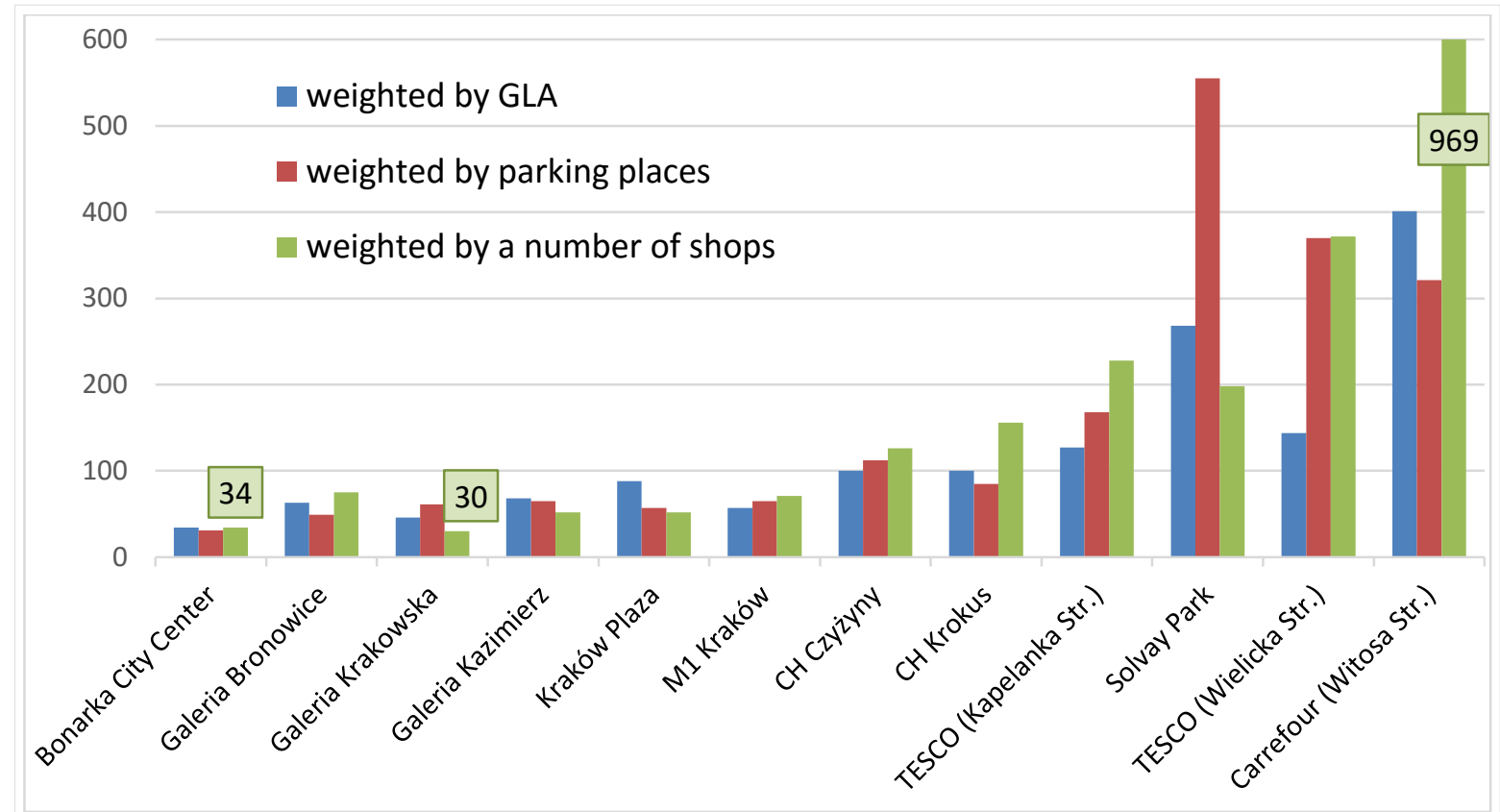

Fig. 9 - Potential measures based on Euclidean distances

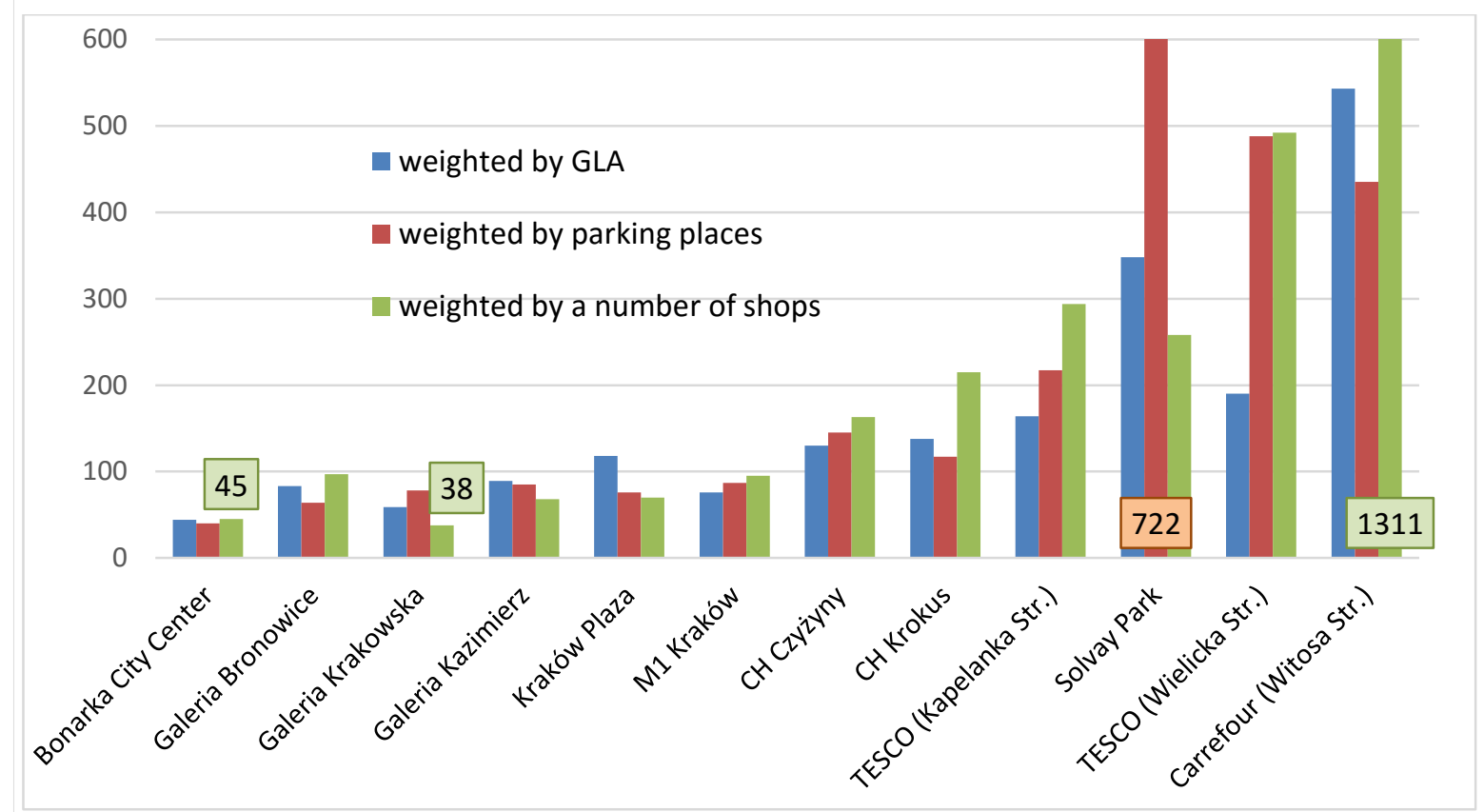

Fig. 10 - Potential measures based on real distances

After analysis of each measure for all shopping malls and considering the difficulty to compare calculated values directly, accessibility ranking of shopping malls was created, which is shown in Table 2.

According to the Table 2, it is possible to conclude, which shopping mall or group of shopping malls in Krakow have the best/ the worst calculated values. Cumulative ranking shows that Galeria Krakowska and Bonarka City Center have the best level of accessibility for both versions of distances. They are representatives of the third and fourth generations respectively. Shopping centers of these generations are characterized by a large GLA surface, large numbers of parking places and shops. In addition, they are situated in a good 
range of distances for an average city inhabitants. Shopping malls of the first and second generations have the worst level of accessibility. Solvay Park, TESCO (Wielicka Str.) and Carrefour (Witosa Str.) presents the smallest level for both versions of distances. Also it must be point out that results for both versions are similar.

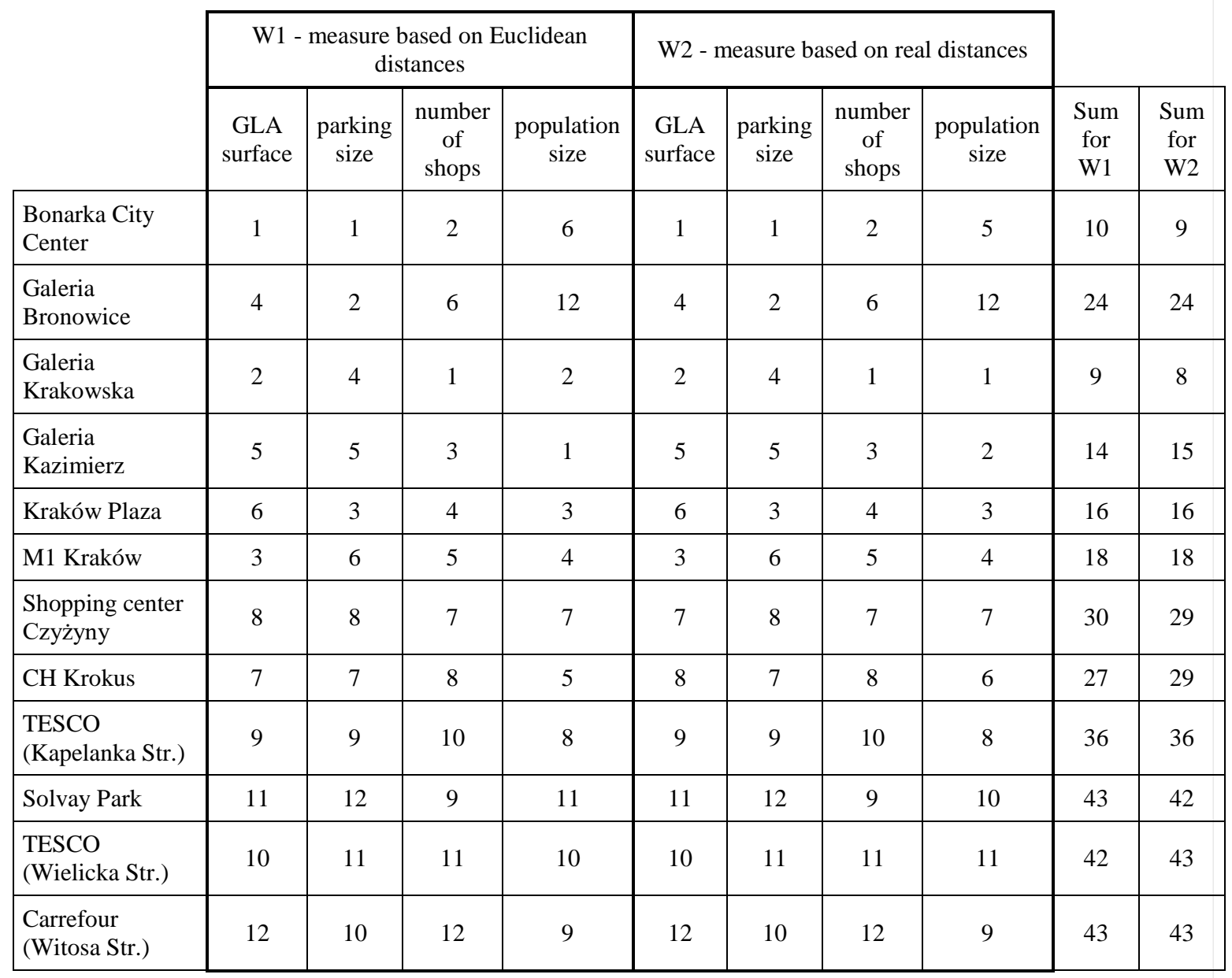

\section{Table 2 - Accessibility rankings of shopping malls in the city of Krakow}

The research study and analysis done within the scope of this study can be a source of information for managers of shopping centers as well as for potential investors. Calculated weights as important factors to demonstrate the attractiveness of shopping centers can characterize the choice of a particular shopping center between possible set.

Further development of this topic could cover analysis of other types of accessibility measures as well as deeper analysis of shopping malls accessibility in the perspective of transport districts and their features.

\section{References}

[1] BEN-AKIVA, M. and LERMAN, S.R. (1979). Disaggregate travel and mobility choice models and measures of accessibility. Behavioural Travel Modelling. Croom Helm, Andover, Hants, pp. 654-679.

[2] BURNS, L.D. (1979). Transportation, Temporal and Spatial Components of Accessibility. Lexington Books, Lexington/Toronto 1979. 
[3] DALVI, M.Q. and MARTIN, K.M. (1976). The measurement of accessibility: some preliminary results. Transportation 5. pp. 17-42.

[4] GEURS, K. and VAN ECK, J.R. (2001). Accessibility measures: review and applications. RIVM.

[5] GEURS, K. and VAN WEE, B. (2013). Accessibility: perspectives, measures and applications. The Transport System and Transport Policy: An Introduction. Edward Elgar, pp. 207-226.

[6] HANSEN, W. G. (1959). How Accessibility Shapes Land Use. Journal of the American Institute of Planners vol 25. pp 73-76.

[7] JOHNSTON, R.J., GREGORY, D. and SMITH, D.M. (1994). The dictionary of human geography: Third Edition. Blackwell Publishers Ltd. Oxford.

[8] NAKKASH, T.Z. (1969). Activity-accessibility models of trip Generation - number 10. JHRP, Purdue University and Indiana State Highway Commission.

[9] SPIKERMANN, K. and others. (2011). TRACC Transport Accessibility at Regional/Local Scale and Patterns in Europe. ESPON \& Spiekermann \& Wegener, Urban and Regional Research (S\&W).

[10] TYLER, N. (1999). Measuring accessibility to public transport. Centre for Transport Studies. University of London. London.

[11] VICKERMAN, R. W. (1974). Accessibility, attraction, and potential: a review of some concepts and their use in determining mobility. Environment and Planning A, 6(6). pp. 675-691.

[12] WEGENER, M. (2004). Overview of land-use transport models. Transport Geography and Spatial Systems. Handbook 5 of Handbook in Transport. Kidlington, UK: Pergamon/Elsevier Science. pp. 127-146.

[13] CICHOCIŃSKI, P. (2012). Ocena przydatności OpenStreetMap jako źródła danych dla analiza sieciowych, Roczniki Geomatyki. pp. 15-24

[14]PASHKEVICH, A. (2014). Realization of OpenStreetMap project possibilities: special GIS software described by using case study of transport infrastructure, Section Cartography and GIS. pp. 799-806.

[15]DROP, P., GAJEWSKI, P., MACKIEWICZ, M. (2013). Zastosowanie danych OpenStreetMap oraz wolnego oprogramowania do badań dostępności komunikacyjnej w skali lokalnej, Acta Universitatis Lodziensis. Folia Geographica Socio-Oeconomica, pp. 157-167

[16]PIĄTKOWSKI, M. (2012). Zastosowanie map OSM w budowie modelu sieci aglomeracji poznańskiej dla symulacji w MATSim, Zeszyty Naukowo-techniczne SITK RP: Oddział w Krakowie, nr 2. pp. 163-177. 